\title{
Manajemen Pendidikan Karakter Berbasis Al-Qur’an, Al-Hadits dan Ijtihad
}

\author{
Zaenal Abidin \\ Fakultas Teknik, Unversitas Pasundan, Bandung, Indonesia \\ Email: abidinzaenal322@gmail.com
}

\begin{abstract}
Manajemen adalah suatu upaya atau usaha dalam mengelola sebuah organisasi atau lembaga secara efektif, efisien, dan profesional. Sedangkan manajemen pendidikan karakter adalah sebuah proses yang dilakukan secara bersama, melibatkan banyak orang, dan lembaga dalam rangka mewujudkan cita-cita tujuan pendidikan nasional, agar peserta didik menjadi manusia yang beriman, bertakwa kepada Tuhan Yang Maha Esa, dan berakhlak mulia. Pendidikan karakter bukan hanya mengajarkan kecerdasan intelektual semata kepada peserta didik ( murid ), akan tetapi juga pendidikan karakter menanamkan kesadaran akan pentingnya nilai-nilai moral, sopan santun, budi pekerti, toleran, moderat, rendah hati, dan berakhlak mulia. Di sisi lain, jauh sebelum manusia mengenal istilah pendidikan karakter, Al-Qur'an telah mengajarkan kepada umat manusia akan pentingnya pendidikan karakter,yaitu : agar manusia pandai bersyukur, atas segala nikmat pemberian Tuhan, berbuat baik kepada kedua ibu dan bapak, serta peduli terhadap sesama. Al-Qur'an juga membimbing manusia agar menjadi pribadi-pribadi yang unggul. Yaitu pribadi yang gemar membaca, yang mengenal jati dirinya,mengenal Tuhannya,suka menulis, dan penelitian menjadi kebutuhan hidupnya. Bahkan hadits Nabi dengan jelas dan tegas menjelaskan, bahwa manusia sejak lahir sudah membawa potensi pendidikan karakter, yakni : memiliki hati nurani yang baik dan pemikiran yang baik pula,sehingga dapat mengembangkan potensi dirinya sesuai dengan tuntutan dan perkembangan zaman

Kata Kunci: manajemen, pendidikan, al-qur'an, al-hadits, ijtihad
\end{abstract}

\begin{abstract}
Management is an effort or effort in managing an organization or institution effectively, efficiently and professionally. Meanwhile, character education management is a process that is carried out jointly, involving many people and institutions in order to realize the ideals of national education goals, so that students become human beings who believe, fear God Almighty, and have noble morals. Character education not only teaches intellectual intelligence only to students, but also character education instills awareness of the importance of moral values, courtesy, character, tolerance, moderation, humility, and noble character. On the other hand, long before humans recognized the term character education, the Al-Qur'an has taught mankind the importance of character education. Namely: so that humans can be smart to be grateful, for all the blessings given by God, to do good to both mothers and fathers, and to care for others. Al-Qur'an also guides people to become superior individuals. Namely, a person who likes reading, who knows his identity, knows his God, likes to write, and research is his life necessity. Even the hadith of the Prophet clearly and emphatically explains, that since birth humans have brought the potential for character education, namely: having a good conscience and good thinking, so that they can develop their potential in accordance with the demands and developments of the times
\end{abstract}




\section{PENDAHULUAN}

Manjemen adalah suatu upaya atau usaha dalam mengelola suatu pekerjaan secara terstruktur, efektif, dan efisien, yaitu proses atau kerangka kerja, yang melibatkan bimbingan atau pengarahan suatu kelompok orang dalam sebuah wadah organisasi dalam mewujudkan suatu cita-cita yang nyata. Atau lebih jelasnya, manajemen adalah sebuah proses perencanaan, pelaksanaan,dan pengawasan dalam sebuah organisasi atau lembaga perusahaan agar cita-cita dan tujuan organisasi dapat terwujud.

Sedangkan manajemen pendidikan yaitu suatu proses kerja sama yang sistematik, sistemik, dan komprehensif dalam mewujudkan tujuan pendidikan nasional.

Pada sisi lain, Al-Qur'an adalah merupakan dasar pendidikan karakter, ia sebagai kitab suci yang sempurna, lengkap, dan sumber inspirasi bagi dunia pendidikan. Sementara Al-Hadits/As-Sunnah menjelaskan lebih rinci dan lebih jelas tentang aspek-aspek yang termaktub dalam Al-Qur'an. Sedangkan ijtihad yang dilakukan dan dikembangkan para ulama dan para pakar pendidikan adalah untuk memelihara dan menjawab masalah-masalah baru dan krusial yang di zaman baginda Nabi Saw, belum ada. Masalah-masalah baru dalam dunia pendidikan senantiasa hadir di tengah-tengah kehidupan umat manusia. Hal ini terjadi karena adanya tuntutan hidup dan perkembangan zaman, yang dari hari ke hari semakin berkembang dan mengglobal. Oleh karena itu, untuk menjawab tantangan tadi para ulama (mujtahid) dan tokoh-tokoh pendidikan nasional melakukan upaya-upaya konkrit, salah satunya adalah dengan melakukan ijtihad dengan merujuk kepada sumber hukum pokok yaitu al-Qur'an dan Al-Hadits/As-Sunnah.

\section{Manajemen Pendidikan}

Gaffar (1989 ) dikutip oleh E. Mulyasa mengemukakan bahwa manajemen pendidikan mengandung arti sebagai suatu proses kerja sama yang sistematik, sistemik, dan komprehensif dalam rangka mewujudkan tujuan pendidikan nasional. Manajemen pendidikan juga dapat diartikan sebagai segala sesuatu yang berkenaan dengan pengelolaan proses pendidikan untuk mencapai tujuan yang telah ditetapkan, baik tujuan jangka pendek, menengah, maupun tujuan jangka panjang.

Manajemen atau pengelolaan merupakan komponen integral dan tidak dapat dipisahkan dari proses pendidikan secara keseluruhan. Alasannya tanpa manajemen tidak mungkin tujuan pendidikan dapat diwujudkan secara optimal, efektif, dan efisien. Sementara fungsi-fungsi manajemen menurut E. Mulyasa yaitu perencanaan, pelaksanaaan, pengawasan, dan pembinaan. Dalam prakteknya keempat fungsi tersebut merupakan suatu proses yang berkesinambungan.

Selanjutnya, keempat fungsi tersebut dapat dideskripsikan sebagai berikut: Perencanaan merupakan proses yang sistematis dalam pengambilan keputusan tentang tindakan yang akan dilakukan pada waktu yang akan datang. Perencanaan juga merupakan kumpulan kebijakan yang secara sistematik disusun dan dirumuskan berdasarkan data yang dapat dipertanggungjawabkan serta dapat dipergunakan sebagai pedoman kerja. Dalam perencanaan terkandung makna pemahaman terhadapa apa yang telah dikerjakan, permasalahan yang dihadapi dan alternatif pemecahannya, serta untuk melaksanakan prioritas kegiatan yang telah ditentukan secara proporsional. Perencanaan program pendidikan sedikitnya memiliki dua fungsi utama, pertama, perencanaan merupakan upaya sistematis yang menggambarkan penyusunan rangkaian tindakan yang akan dilakukan untuk mencapai tujuan organisasi atau lembaga dengan mempertimbangkan sumber-sumber yang dapat disediakan; kedua, perencanaan merupakan kegiatan

Volume 1, Nomor 1 November 2018 
untuk mengerahkan atau menggunakan sumber-sumber yang terbatas secara efisien dan efektif untuk mencapai tujuan yang telah ditetapkan .

Pelaksanaan merupakan kegiatan untuk merealisasikan rencana menjadi tindakan nyata dalam rangka mencapai tujuan secara efektif dan efisien. Rencana yang telah disusun akan memiliki nilai jika dilaksanakan dengan efektif dan efisien. Dalam pelaksanaan, setiap organisasi harus memiliki kekuatan yang mantap dan meyakinkan sebab jika tidak kuat, maka proses pendidikan seperti yang diinginkan sulit terealisasi.

Pengawasan dapat diartikan sebagai upaya untuk mengamati secara sistematis dan berkesinambungan, merekam, memberi penjelasan, petunjuk, pembinaan dan meluruskan berbagai hal yang kurang tepat, serta memperbaiki kesalahan. Pengawasan merupakan kunci keberhasilan dalam keseluruhan proses manajemen, perlu dilihat secara komprehensif, terpadu, dan tidak terbatas pada hal-hal tertentu.

Pembinaan merupakan rangkaian upaya pengendalian secara profesional semua unsur organisasi agar berfungsi sebagaimana mestinya sehingga rencana untuk mencapai tujuan dapat terlaksana secara efektif dan efisien. (E. Mulyasa, 2017, h. 20- 2 ).

\section{Pendidikan Karakter}

Menurut E.Mulyasa, pendidikan karakter memiliki makna lebih tinggi dari pendidikan moral, karena pendidikan karakter tidak hanya berkaitan dengan masalah benar salah, tetapi bagaimana menanamkan kebiasaan (habit) tentang halhal yang baik dalam kehidupan, sehingga anak/peserta didik memiliki kesadaran, dan pemahaman yang tinggi, serta kepedulian dan komitmen untuk menerapkan kebajikan dalam kehidupan sehari-hari. Dengan demikian dapat dikatakan bahwa karakter merupakan sifat alami seseorang dalam merespon situasi secara bermoral, yang diwujudkan dalam tindakan nyata melalui perilaku baik, jujur, bertanggung jawab, hormat terhadap orang lain, dan nilai-nilai karakter mulia lainnya. Dalam konteks pemikiran Islam, karakter berkaitan dengan iman dan ikhsan. Hal ini sejalan dengan ungkapan Aristoteles, bahwa karakter erat kaitannya dengan "habit" atau kebiasaan yang terus-menerus dipraktikkan dan diamalkan. ( E. Mulyasa, h.03 ).

Wynne (1991) dikutip oleh E. Mulyasa mengemukakan bahwa karakter berasal dari bahasa Yunani yang berarti " $t o$ mark " (menandai) dan memfokuskan pada bagaimana menerapkan nilai-nilai kebaikan dalam tindakan nyata atau perilaku seharihari. Oleh sebab itu, seseorang yang berprilaku tidak jujur, curang, kejam, dan rakus dikatakan sebagai orang yang memiliki karakter jelek, sedangkan yang berprilaku baik, jujur, dan suka menolong dikatakan sebagai orang yang memiliki karakter baik /mulia. Dalam pendidikan karakter diperlukan juga aspek perasaan (emosi), yang oleh Lickona ( 1992 ) disebut "desiring the good" atau keinginan untuk melakukan kebajikan. Dalam hal ini ditegaskan bahwa pendidikan karakter yang baik harus melibatkan bukan saja aspek knowing the good, tetapi juga desiring the good atau loving the good dan acting the good, sehingga manusia tidak berprilaku seperti robot yang diindoktrinasi oleh paham tertentu. ( E.Mulyasa : 04 ).

Hampir sama dengan yang di atas, Anas Salahudin mengemukakan, karakter adalah nilai-nilai yang khas baik (tahu nilai kebaikan, mau berbuat baik, nyata berkehidupan baik, dan berdampak baik terhadap lingkungan) yang terpatri dalam diri dan terwujud dalam prilaku.

Karakter secara koheren memancar dari hasil olah pikir,olah hati,olah raga, serta olah rasa dan karsa seseorang atau sekelompok orang. Karakter merupakan ciri khas seseorang atau sekelompok orang yang mengandung nilai, kemampuan, kapasitas 
moral, dan ketegaran dalam menghadapi kesulitan dan tantangan.

Hubungannya dengan pendidikan, pendidikan karakter dapat dimaknai sebagai pendidikan nilai, pendidikan budi pekerti, pendidikan moral, pendidikan watak, yang bertujuan mengembangkan kemampuan siswa untuk memberikan keputusan baik buruk, memelihara kebaikan, mewujudkan dan menebar kebaikan dalam kehidupan sehari-hari dengan sepenuh hati. (Anas Salahudin : 42).

Menurut Marzuki bahwa karakter identik dengan akhlak sehingga karakter merupakan nilai-nilai prilaku manusia yang universal yang meliputi seluruh aktivitas manusia baik dalam rangka berhubungan dengan Tuhan, diri sendiri, sesama manusia, maupun lingkungan yang terwujud dalam pikiran, sikap, perasaan, perkataan, dan perbuatannya berdasarkan norma-norma agam, hukum, tata krama, budaya, dan adat istiadat. Dari konsep karakter ini muncul konsep pendidikan karakter (character education). Ahmad Amin (1995:62) mengemukakan bahwa kehendak (niat) merupakan awal terjadinya akhlak (karakter) pada diri seseorang jika kehendak itu diwujudkan dalam bentuk pembiasaan sikap dan prilaku.

Konsep pendidikan karakter dikenalkan sejak tahun 1900-an. Meskipun banyak ahli yang menggunakan konsep ini sekarang, Thomas Lickona-lah yang dianggap sebagai tokoh yang mempopulerkannya, terutama ketika ia menulis bukunya yang berjudul Educating for Character: How Our School Can Teach Respect and Responsibility (1991) yang kemudian disusul oleh tulasan-tulisannnya, seperti "The Return of Character Education yang dimuat dalam jurnal Educational Leadership ( November 1993 ), "Eleven Principles of Effective Character Education" yang dimuat dalam journal of Moral Volume 25 ( 1996 ), serta buku character Matters : How to Help Our Children Develop Good Judgment, Integrity, and Other Essential
Virtues ( 2004 ). Melalui buku-buku dan tulisan-tulisannya itu, Lickona menyadarkan dunia akan pentingnya pendidikan karakter. Menurutnya, pendidikan mengandung tiga unsur pokok, yaitu mengetahui kebaikan (knowing the good), mencintai kebaikan (desiring the good), dan melakukan kebaikan (doing the good) (Lickona, 1991: 51 ).

Di pihak lain, Frye (2002: 2) mendefinisikan pendidikan karakter sebagai a national movement creating schools that foster ethical, responsible, and caring young people by modeling and teaching good character through an emphasis on universal values that we all share. (Suatu gerakan nasional untuk menciptakan sekolah yang dapat membina anak-anak muda beretika, bertanggung jawab, dan peduli melalui keteladanan dan pengajaran karakter yang baik melalui penekanan pada nilai-nilai universal yang kita sepakati bersama. Jadi, pendidikan karakter, menurut Frye, harus menjadi gerakan nasional yang menjadikan sekolah sebagai agen untuk membudayakan nilai-nilai karakter mulia melalui pembelajaran dan pemberian contoh (model). Melalui pendidikan karakter sekolah harus berpretensi untuk membawa peserta didik memiliki nilai-nilai karakter mulia, seperti hormat dan peduli kepada orang lain, tanggung jawab, memiliki integritas, serta disiplin. Di sisi lain, pendidikan karakter juga harus mampu menjauhkan peserta didik dari sikap dan perilaku yang tercela dan dilarang. Pendidikan karakter tidak hanya mengajarkan mana yang benar dan mana yang salah kepada peserta didik, tetapi juga menanamkan

kebiasaan

(habituation) tentang yang baik sehingga peserta didik paham, mampu merasakan, dan mau melakukannya. Dengan demikian, pendidikan karakter membawa misi yang sama dengan pendidikan akhlak atau pendidikan moral. Selanjutnya, Frye (2002:3) menegaskan bahwa pendidikan karakter merupakan usaha yang disengaja untuk membantu seseorang memahami, menjaga, dan berprilaku yang sesuai dengan 
nilai-nilai karakter mulia. Pendidikan karakter tidak bisa dibiarkan jalan begitu saja tanpa adanya upaya-upaya cerdas dari para pihak yang bertanggung jawab terhadap pendidikan. Tanpa upaya-upaya cerdas, pendidikan karakter tidak akan menghasilkan manusia yang pandai sekaligus menggunakan kepandaiannya dalam rangka bersikap dan berprilaku baik ( berkarakter mulia ). (Marzuki, Pendidikan Karakter Islam, h. 21-23).

Pendidikan karakter adalah sebuah sistem pemurnian nilai nilai karakter kepada warga sekolah yang meliputi komponen pengetahuan kesadaran, atau kemauan, dan tindakan untuk melakukan nilai-nilai tersebut. Pendidikan karakter dapat dimaknai sebagai "The deliberate use of all dimension of school life to fuster, Optimal caracter development". Menurut Aan Hasanah dalam pendidikan karakter itu di sekolah, semua komponen (pemangku pendidikan) harus dilibatkan termasuk kompenen-komponen pendidikan itu sendiri. Yaitu isi kurikukulum, proses pembelajaran dan penilaian, penganganan atau pengelolaan mata pelajaran, penegelolaan sekolah, pelaksanaan aktivitas atau kegiatan extrakurikuler, pemberdayaan sarana prasarana, pembiayaan, dan etos kerja seluruh warga sekolah maupun lingkungan. Di samping itu, pendidikan karakter di maknai sebagai suatu perilaku warga sekolah yang dalam menyelenggaraan pendidikan harus berkarakter.

Dalam sisi lain pendidikan karakter adalah segala sesuatu yang dilakukan guru, yang mampu mempengaruhi karakter peserta didik, guru membantu watak serta didik. Hal ini mencakup keteladanan bagaimana perilaku guru, cara guru berbicara atau menyampaikan materi, bagaimana guru bertoleransi, dan berbagai hal terkait lainnya.

Pendidikan karakter berpijak dari karakter dasar manusia, yang bersumber dari nilai moral universal (bersifat Absolute) dan bersumber dari agama juga disebut sebagai The Golden Rule. Pendidikan karakter dapat memiliki tujuan yang pasti, apabila berpijak dari nilai-nilai karakter dasar tersebut. Menurut para ahli psikologi, beberapa nilai karakter dasar tersebut adalah cinta kepada Allah dan Ciptaan-Nya. (Alam dengan isinya) Tanggung jawab jujur, hormat dan santun, kasih sayang, peduli, dan kerja sama, percaya diri, kreatif, kerja keras, dan pantang menyerah, keadilan dan kepemimpinan, baik dan rendah hati, toleransi cinta damai, dan cinta persatuan.

Pendapat lain menyatakan bahwa karakter dasar manusia terdiri dari: Dapat di percaya, rasa hormat, perhatian, peduli, jujur, tanggung jawab kewarganegaraan, ketulusan, berani, tekun , disiplin, visioner, adil, dan punya intregritas.

\section{Dasar Pendidikan Karakter}

Islam merupakan agama yang sempurna, sehingga setiap ajaran yang ada dalam Islam memiliki dasar pemikiran, begitu pula dengan pendidikan karakter. Adapun yang menjadi dasar pendidikan karakter adalah Al-Qur'an, Al-Hadits dan taqwa, dengan kata lain dasar-dasar yang senantiasa dikembalikan kepada AlQur'an, Al-Hadits, serta ketakwaan kepada Allah SWT. ( Syafri, Ulil Amri, 2012 ).

Menurut Said Ismail Ali dikutip oleh M. Akmansyah, Al-Qur'an menduduki tempat paling depan dalam pengambilan sumber-sumber pendidikan lainnya. Segala kegiatan dan proses pendidikan Islam haruslah senantiasa berorientasi kepada prinsip dan nilai-nilai Al-qur'an. Di dalam Al-qur'an terdapat beberapa hal yang sangat positif guna pengembangan pendidikan. Hal itu, antara lain: penghormatan kepada akal manusia, bimbingan ilmiah,tidak menentang fitrah manusia, serta memelihara kebutuhan sosial.

(Said Ismail Ali, Jurnal Pengembangan Masyarakat Islam, vol.8,no.2, Agustus 2015 ).

Menurut Anas Salahudin, Dasar Pendidikan Karakter sangat identik dengan ajaran setiap agama dan budaya bangsa. Bagi 
umat Islam, sumber dasar pendidikan karakter menurut visi Islam adalah sebagai berikut :

\section{Al-Qur'an}

Al-qur'an menduduki tempat paling depan dalam pengambilan sumber-sumber pendidikan lainnya. Segala kegiatan dan proses pendidikan Islam haruslah senantiasa berorientasi kepada prinsip dan nilai-nilai alqur'an. Di dalam al-qur'an terdapat beberapa hal yang sangat positif guna pengembangan pendidikan. Hal itu antara lain; penghormatan kepada akal manusia, bimbingan ilmiah, tidak menentang fitrah manusia, serta memelihara kebutuhan sosial.

Al-qur'an memiliki pembendaharaan luas dan besar bagi pengembangan kebudayaan umat manusia. Ia merupakan sumber pendidikan yang terlengkap, baik itu pendidikan sosial, moral, spiritual, material serta alam semesta. Al-Qur'an merupakan sumber nilai yang absolut dan utuh. Eksistensinya tidak akan pernah mengalami perubahan. Kemungkinan terjadi perubahan hanya sebatas interpretasi manusia terhadap teks ayat yang menghendaki kedinamisan pemaknaannya, sesuai dengan konteks zaman, situasi ,kondisi, dan kemampuan manusia dalam melakukan interpretasi. Ini merupakan pedoman normatif-teoritis bagi pelaksanaan pendidikan Islam yang memerlukan penafsiran lebih lanjut. (Said Ismail Ali, halam : 192 ).

Menurut H.M. Arifin dikutip oleh M. Akmansyah bahwa pelaksanaan pendidikan Islam harus senantiasa mengacu pada sumber yang termuat dalam Al-Qur'an. Dengan berpegang kepada nilai-nilai yang terkandung dalam al-qur'an, terutama dalam pelaksanaan pendidikan Islam, akan mampu mengarahkan dan mengantarkan manusia bersifat dinamis-kreatif serta mampu mencapai esensi nilai-nilai ubudiyah pada penciptanya. Dengan sikap ini, maka proses pendidikan Islam akan senantiasa terarah dan mampu menciptakan dan mengantarkan out putnya sebagai manusia berkualitas dan bertanggung jawab terhadap semua aktivitas yang dilakukannya.

Al-Qur'an memiliki misi dan implikasi kependidikan yang bergaya imperatif, motivatif, dan persuasivedinamis, sebagai suatu sistem pendidikan yang utuh dan demokrasi lewat proses manusiawi. Proses kependidikan tersebut bertumpu pada kemampuan rohaniah dan jasmaniah masing-masing individu peserta didik, secara bertahap dan berkesinambungan, tanpa melupakan kepentingan perkembangan zaman dan nilainilai Ilahiah. Kesemua proses kependidikan Islam tersebut merupakan proses konservasi dan transformasi, serta internalisasi nilainilai dalam kehidupan manusia sebagaimana yang diinginkan oleh ajaran Islam. Dengan upaya ini, diharapkan peserta didik mampu hidup secara serasi dan seimbang, dalam kehidupan di dunia maupun di akhirat. (Jurnal Pendidikan Islam, vol.8, No 2, Agustus 2015 ).

Bagi umat Islam kitab suci Al-Qur'an adalah firman Allah SWT, yang diturunkanNya melalui perantaraan malaikat Jibril kepada Rasul-Nya, Nabi Muhammad SAW. Dalam kitab suci Al-Qur'an telah termaktub seluruh aspek pedoman hidup bagi umat Islam, sehingga kitab suci Al-Qur'an merupakan falsafah hidup muslim, baik di dunia maupun di akhirat kelak. Kitab suci Al-Qur'an merupakan ajaran Islam yang universal, baik dalam bidang akidah, ibadah, akhlak,maupun muamalah. Dengan luasnya cakupan dalam aspek ekonomi, sosial, budaya, politik, pertahanan dan keamanan ataupun aspek pendidikan.

Hal tersebut sangat sesuai dengan firman Allah SWT. yang menjelaskan :

“ Kitab ( Al-Qur'an ) yang Kami turunkan kepadamu penuh berkah agar mereka menghayati ayat-ayatnya dan agar orangorang yang berakal sehat mendapat pelajaran. Kemudian ( Q.S. Shad (38) : 29 ) yang artinya : 
Dan Kami tidak menurunkan Kitab AlQur'an; ini kepadamu (Muhammad), melainkan agar engkau dapat menjelaskan kepada mereka apa yang mereka perselisihkan itu, serta menjadi petunjuk dan rahmat bagi orang-orang yang beriman." (Anas Salahudin, halaman : 81- 82 ).

Diantara ayat Al-Qur'an yang mendasari pendidikan karakter adalah :

a. Qs. Lukman /31 : 12

"Dan sungguh telah Kami beri Lukman ilmu pengetahuan alhikmah), bersyukurlah kamu kepada Allah. Barangsiapa bersyukur kepada-Nya maka sesungguhnya untuk dirinya sendiri. Barangsiapa kufur kepada Allah maka sesungguhnya Allah Maha Kaya lagi Maha Terpuji. “”

Menurut Al-Ghazali, bahwa syukur adalah perilaku orang-orang saleh terdahulu (salafusshalihin), yaitu para sahabat, para tabiien dan tabiit tabiien. Nilai pendidikan karakter yang termaktub dalam surat ini adalah bahwa Lukman seorang pribadi yang pandai bersyukur. Syukur yang dilakukan oleh seorang 'alim mendapatkan tempat di sisi Allah manakala menapaki tiga tahapan. Pertama, perilaku seorang siswa sejatinya sejalan dengan perintah Allah SWT. Barangsiapa beribadah kepada Allah niscaya ia akan mengenal-Nya (al-'alim). Kedua, seorang muslim (siswa) yang baik, ketika ia mendapatkan rezeki dari Allah, maka ia menerimanya dengan baik, penuh dengan suka cita dan menerima apa adanya. Ketiga, ketika ia diberi nikmat oleh Allah, maka ia akan melakukan aksi (action) yang berguna bagi orang lain. (Al-Ghazali, Ihya 'Ulumuddin,jilid 4, h. 364).

b. Qs. Lukman/31 : 13

"Dan ( ingatlah) ketika Lukman berkata kepada anaknya di waktu ia memberi pelajaran kepadanya: “ Hai anakku, janganlah kamu mempersekutukan Allah, sesungguhnya mempersekutukan
Allah adalah benar-benar kezaliman yang besar".

Menurut Ali AS-Shabuni, sesungguhnya syirik itu kotor, dan zalim itu jelas sesatnya. Karena zalim itu adalah meletakan sesuatu bukan pada tempatnya. Karena sesungguhnya telah jelas bedanya antara Tuhan (Al-Khalik) dan manusia (almakhluk), antara Allah dan patung. Maka tidak ragu lagi orang yang menyekutukan Allah adalah sebodoh bodoh nya manusia, jauh dari nalar sehat dan hikmah. Perbuatan seperti ini sifat orang zalim yang digolongkan seperti hewan melata.

c. Qs. Lukman /31 : 14

" Dan Kami perintahkan kepada manusia ( berbuat baik) kepada dua orang ibu bapaknya, ibunya telah mengandung dalam keadaan lemah yang bertambah-tambah, dan menyapihnya dalam dua tahun. Bersyukurlah kepada-Ku dan kepada dua orang ibu bapakmu, hanya kepada-Kulah kembalimu”"

Nilai pendidikan karakter yang terkandung dalam ayat ( Qs.Lukman/31:14) adalah sebagai berikut :

a. Bahwa Allah SWT. memerintahkan kepada kita agar berbuat baik kepada dua ibu bapak

b. Ibu telah mengandung dia selama sembilan bulan dalam keadaan lemah yang bertambah tambah.

c. Ibu menyapih anaknya ketika umur dua tahun.

d. Bersyukurlah kepada Allah yang telah memberi nikmat iman dan nikmat ihsan ( akhlak yang baik ).

e. Bersyukurlah kepada kedua orang ibu bapak, ibu telah mengadung dia selama sembilan bulan dan menyapihnya ketika umur dua tahun, serta mendidiknya hingga ia dewasa.

d. QS. Al-Alaq/ $96: 1-5$ ).

Salah satu bukti bahwa Islam adalah agama universal dan abadi adalah di 
dalamnya terdapat petunjuk-petunjuk tentang ilmu, semua orang pasti membutuhkan ilmu, karena ilmu itu sendiri setua manusia.

"Bacalah dengan menyebut nama Tuhanmu Yang menciptakan. Dia telah menciptakan manusia dari segumpal darah. Bacalah dan Tuhanmulah Yang Maha Pemurah. Yang mengajar manusia dengan perantaraan qalam. Dia mengajarkan manusia apa yang tidak diketahuinya. "

Menurut As-Shabuni, ayat ini awal dari perintah Allah kepada Nabi Saw. Di dalamnya terkandung nilai pendidikan (ajaran) agar manusia gemar membaca, membaca buku, membaca kitab, dan membaca perkembangan zaman. Budaya membaca merupakan syi'ar ajaran Islam. Baca ya Muhammad Al-Qur'an ketika memulai semua kegiatan dan Tuhan telah menciptakan dan minta tolonglah dengan menyebut nama Tuhanmu yang Agung, Tuhan telah menciptakan seluruh makhluk dan menjadikan seluruh alam, kemudian jelaskan kepada seluruh makhluk tentang keagungan-Nya di dalam menciptakan manusia. ( As-Shabuni, h. 581 ).

Ayat di atas, mengandung arti bahwa umat manusia agar menjadi umat yang unggul dan maju, menguasai iptek dan sekaligus mampu memelihara hubungan baik dengan Allah.

Dia telah menciptakan manusia dari segumpal darah. Tegasnya, Allah SWT, telah menciptakan manusia dengan bentuk yang unik, menciptakan manusia dengan bentuk yang paling sempurna, dia berasal dari segumpal darah ('alaqah) yakni setetes air hina. Hal ini seperti keterangan dalam hadits :

"Sesungguhnya manusia itu diciptakan dari air mani yang secara fisik sejajar dengan hewan. Dengan mengetahui sejajar asal kejadiannya dari segumpal darah itu diharapkan tidak angkuh dan sombong. Karena keangkuhan dan kesombongan itu bukan pakaian manusia tetapi pakaian Tuhan yang berhak disembah oleh semua insan.

Al-Qurtubi mengatakan : Bahwa kehususan manusia itu dengan dzikir dan kemuliannya.

"Bacalah dan Tuhanmu-lah yang mulia lagi pemurah. Ayat ini memberi arti : Bacalah Ya Muhammad, kebesaran Tuhanmu yang Maha Besar dan Maha Mulia, Tuhan yang tidak ada persamaan-Nya, tidak ada yang mengungguli kemuliaan-Nya yang telah menunjukan jalan kesempurnaan dan kemuliaan, yang telah mengajarkan hamba-hamba-Nya yang mereka tidak mengetahui sebelumnya. ( AsShabuni , h.582 ). Ayat ini merupakan penegasan agar manusia menjadi umat yang berkualitas, mampu menjadi pelopor dan penggerak kemajuan ilmu pengetahuan dan peradaban ( Al-Islam dan Iptek, ).

Yang mengajar manusia dengan perantaraan kalam ( pena). Allah telah mengajarkan baca tulis dengan kalam (pena), mengajarkan manusia apa-apa yang tidak mereka tidak tahu berupa ilmu pengetahuan dan kebijaksanaan, menjadikan mereka dari situasi kegelapan (kebodohan) ke suasana terang menderang. Allah telah mengajarkan manusia dengan perantaraan tulisan dan pena. Manakala Dia tidak mengajarkan kamu maka kamu dalam keadaan ummi tentu tidak dapat membaca dan menulis.

Bagi umat Islam kitab suci Al-Qur'an adalah firman Allah SWT, yang diturunkanNya melalui perantaraan malaikat Jibril kepada Rasul-Nya, Nabi Muhammad SAW. Dalam kitab suci Al-Qur'an telah termaktub seluruh aspek pedoman hidup bagi umat Islam, sehingga kitab suci Al-Qur'an merupakan falsafah hidup muslim, baik di dunia maupun di akhirat kelak. Kitab suci AlQur'an merupakan ajaran Islam yang universal, baik dalam bidang akidah, ibadah, akhlak, maupun muamalah.

Menurut Al-Qurtubi, Allah SWT, memberikan pengajaran tentang keutamaan ilmu dan tulisan, karena di dalamnya terdapat beberapa manfaat yang sangat besar, karena tanpa bantuan ilmu Allah manusia tidak akan 
dapat memuliakan ilmu, tidak mampu membuat rumusan-rumusan hukum, tidak akan dapat menginformasikan cerita-cerita masa lalu dengan akurat dan benar. Allah SWT tidak merumuskan dalam kitab-Nya kecuali dengan tulisan dan tidak akan pula mampu menjelaskan semua masalah, baik masalah dunia ataupun masalah akhirat. ( AsShabuni, jilid lll, h. 582 ).

Ayat di atas, memberi gambaran kepada kita bahwa belajar tidak cukup membaca, tapi juga harus menulis, karena tulisan banyak memberi manfaat kepada penulisnya. Hal ini sebagaimana kata ulama : Ilmu itu laksana buronan ( liar ), maka ikatlah buronan itu dengan tali yang kuat(tulisan).

Dia mengajarkan kepada manusia apa yang tidak diketahuinya. ('allama alinsana ma lam ya'lam ). Ayat ini menyuruh manusia agar gemar mengadakan penelitian. Dari penelitian ini maka akan terungkaplah ilmu-ilmu baru, yang semula samar-samar maka menjadi jelas.

\section{Al-Sunnah (Al-Hadits)}

Al-Hadits merupakan sumber ketentuan Islam yang kedua setelah alqur'an. Ia merupakan penguat dan penjelas dari berbagai persoalan baik yang ada di dalam al-qur'an maupun yang dihadapi dalam persoalan kehidupan umat muslim yang disampaikan dan dipraktikkan Nabi Muhammad Saw, yang dapat dijadikan landasan pendidikan Islam .

Kedudukan Al-Hadits dalam kehidupan dan pemikiran Islam sangat penting, karena disamping memperkuat dan memperjelas berbagai persoalan dalam alqur'an, juga memberikan dasar pemikiran yang lebih konkret mengenai penerapan berbagai aktivitas yang mesti dikembangkan dalam kerangka hidup dan kehidupan umat Islam. Banyak hadits nabi yang memiliki relevansi ke arah dasar pemikiran dan implikasi langsung bagi pengembangan dan penerapan dunia pendidikan .
Contoh yang telah ditunjukkan Nabi (Al-Hadits), merupakan sumber dan acuan yang dapat digunakan umat Islam dalam seluruh aktivitas kehidupannya. Meskipun secara umum bagian terbesar dari syariat Islam telah terkandung dalam al-qur'an, namun muatan tersebut belum mengatur berbagai dimensi aktivitas kehidupan umat secara terperinci. Penjelasan syari'ah yang dikandung Al-Qur'an sebagian masih bersifat global. Untuk itu diperlukan keberadaan al-hadits Nabi sebagai penjelas dan penguat bagi hukum-hukum qur'aniah yang ada, sekaligus sebagai petunjuk (pedoman) bagi kemaslahatan hidup manusia dalam semua aspeknya.

Dari sini dapat dilihat bagaimana posisi dan fungsi al-hadits Nabi sebagai sumber pendidikan Islam yang utama setelah al-qur'an. Eksistensinya merupakan sumber inspirasi ilmu pengetahuan yang berisikan keputusan dan penjelasan nabi dari pesanpesan Ilahiah yang tidak terdapat dalam AlQur'an, maupun yang terdapat dalam A1Qur'an, tapi masih memerlukan penjelasan lebih lanjut secara terperinci.

Dalam dataran pendidikan Islam, acuan tersebut dapat dilihat dari dua bentuk, yaitu: pertama, sebagai acuan syari'ah; yang meliputi muatan-muatan pokok ajaran Islam secara teoritis . Kedua, acuan operasionalaplikatif yang meliputi cara Nabi memainkan peranannya sebagai pendidikan dan sekaligus sebagai evaluator yang adil dan tetap menjunjung tinggi nilai-nilai ajaran Islam. Hal itu dapat dilihat dari bagaimana cara Nabi melaksanakan proses belajar mengajar, sehingga dalam waktu singkat mampu diserap oleh para sahabat, evaluasi yang dilaksanakan sehingga bernilai efektif dan efisie, kharisma dan spirit pribadi yang harus ada pada diri seorang pendidik yang telah ditunjukkan Nabi , cara n Nabi memilih materi, alat peraga, dan kondisi yang sebegitu adaptik, maupun cara Nabi dalam menempatkan posisi peserta didiknya, dan lain sebagainya. Kesemua itu merupakan figur yang ada pada diri Rasulullah Saw, dan 
menjadi model bagi seluruh aktivitas manusia sebagai uswah hasanah yang telah dibimbing langsung oleh Allah SWT, sehingga hampir tidak mungkin melakukan kesalahan dalam pelaksanaan proses pendidikannya.

Proses pendidikan Islam yang ditunjukkan Nabi Muhammad Saw, merupakan bentuk pelaksanaan pendidikan yang bersifat fleksibel dan universal, sesuai dengan potensi yang dimiliki peserta didik, kebiasaan masyarakat serta kondisi alam dimana proses pendidikan tersebut berlangsung dengan dibalut oleh pilar-pilar akidah Islamiah.

Dalam konteks ini, pendidikan Islam yang dilakukan Nabi dapat dibagi kepada dua bentuk, yaitu :

Pertama, pola pendidikan saat Nabi di Makah. Pada masa ini, Nabi memanfaatkan potensi masyarakat Makah dengan mengajaknya membaca, memperhatikan dan memikirkan kekuasaan Allah, baik yang ada di alam semesta maupun yang ada dalam dirinya. Melanjutkan tradisi pembuatan syair-syair yang indah dengan nuansa islami, serta pembacaan ayat-ayat alqur'an, merubah kebiasaan masyarakat Makah yang selama ini memulai suatu pekerjaan menyebut nama-nama berhala, dengan nama Allah (Basmalah) dan sebagainya.

Secara konkret, pemetaan pendidikan Islam pada periode ini dapat dibagi pada empat aspek utama, yaitu : pendidikan akhlak dan budi pekerti, dan pendidikan jasmani (kesehatan), seperti menunggang kuda, memanah, dan menjaga kebersihan.

Kedua, pola pendidikan saat Nabi di Madinah. Secara geografis, Madinah merupakan daerah agraris. Sedangkan Makah merupakan daerah pusat perdagangan. Ini membedakan sikap dan kebiasaan masyarakat di kedua daerah tersebut. Masyarakat Madinah merupakan masyarakat petani yang hidup saling membantu antara satu dengan yang lain. Melihat kondisi ini, pola pendidikan yang diterapkan Nabi Saw , lebih berorientasi pada pemantapan nilai-nilai persaudaraan antara kaum Muhajirin dan Anshar pada satu ikatan. Untuk mewujudkan ini, pertama-tama Nabi mendirikan masjid sebagai sarana yang efektif. Materi pendidikannya lebih ditekankan pada penanaman ketauhidan, pendidikan keluarga, pendidikan masyarakat, dan sopan santun (adab). Kesemua ini berjalan cukup efektif, karena di sampaing motivasi internal umat waktu itu, kharisma dan metode yang digunakan Nabi mampu mengayomi seluruh kepentingan masyarakat secara adil dan demokratis. Dengan mengacu pada pola ini menjadikan pendidikan Islam sebagai piranti yang tangguh dan adaptik dalam mengantarkan peserta didiknya membangun peradaban yang bernuansa Islami (rahmatan li al-'lamin) (Akmansyah ,Jurnal Pengembangan Masyarakat Islam, vol.8, No.2, Agustus 2015)

Bagi umat Islam, Nabi Muhammad SAW, merupakan Rasul Allah terakhir yang mengemban risalah Islam. Segala yang berasal dari beliau SAW, baik perkataan, perbuatan, maupun ketetapannya sebagai rasul merupakan sunnah bagi umat Islam yang harus dijadikan panutan. Hal ini karena sebagai Rasul Allah, Nabi Muhammad SAW, senantiasa dibimbing oleh wahyu Allah SWT.

Hal tersebut dijelaskan dalam firman Allah SWT. yang artinya :

“ Sungguh telah ada pada ( diri) Rasulullah itu suri teladan yang baik bagimu ( yaitu ) bagi orang yang mengharap (rahma) Allah dan (kedatangan) hari kiamat dan yang banyak mengingat Allah.

(Q.S.Al-Ahzab (33) : 21).

Ramayulis (2006 : 123) dikutip oleh Anas Salahudin menjelaskan, konsepsi dasar pendidikan yang dicontohkan Nabi Muhammad SAW, adalah sebagai berikut.

1. Disampaikan sebagai rahmatan lil 'alamin, seperti dijelaskan dalam firman Allah SWT. yang artinya : "Dan Kami 
tidak mengutus engkau ( Muhammad) melainkan untuk ( menjadi) rahmat bagi seluruh alam." (Q.S. Al-Anbiya (21) : 107)

2. Disampaikan secara universal.

3. Segala sesuatu yang disampaikan merupakan kebenaran mutlak, seperti firman Allah yang artinya :

“ Sesungguhnya Kamilah yang menurunkan Al-Qur'an, dan pasti Kami (pula) yang memeliharanya." ( Q.S. AlHijr (15) : 9 )

4. Kehadiran Nabi SAW. bagi umat manusia sebagai evaluator atas segala aktivitas pendidikan.

5. Perilaku Nabi Muhammad SAW, merupakan figur identifikasi ( uswah hasanah ) bagi umatnya. Allah SWT berfirman yang artinya : "Sungguh, telah ada pada diri Rasulullah SAW itu suri teladan yang baik bagimu ( yaitu) bagi orang yang mengharap ( rahmat) Allah dan ( kedatangan ) hari Kiamat dan yang banyak mengingat Allah. " ( QS. Al-Ahzab : 21 )( Anas Salahudin, 2013, h. 83-84 ).

6. Teladan para sahabat dan tabiin

Para sahabat dan tabiin merupakan generasi awal Islam yang pernah mendapat pendidikan langsung dari Rasulullah SAW. Oleh karena itu, sikap, perkataan, dan tindakan mereka senantiasa dalam pengawasan Rasulullah SAW. sebagai kader awal dakwah Islam, mereka dapat dijadikan contoh dalam hal perkataan, perbuatan, dan sikapnya selama tidak bertentangan dengan Al-Qur'an dan As-Sunnah. Hal ini dijelaskan dalam firman Allah SWT yang artinya :

“ Wahai orang-orang yang beriman! Bertaqwalah kepada Allah, dan bersamalah kamu dengan orang-orang yang benar. ( Q.S. At-Taubah/ 9 : 119)

" Dan orang-orang yang terdahulu lagi yang pertama-tama ( masuk Islam ) di antara orang-orang Muhajirin dan Anshar dan orang-orang yang mengikuti mereka dengan baik, Allah ridha kepada mereka, dan mereka pun ridha kepada Allah. Allah menyediakan bagi mereka surga-surga yang mengalir di bawahnya sungai-sungai. Mereka kekal di dalamnya selama-lamanya. Itulah kemenangan yang agung." ( Q.S. AtTaubah/9 : 100 ).

\section{3 ) Ijtihad ( Pemikiran Islam )}

Ijtihad adalah penelitian dan pemikiran untuk mendapatkan sesuatu yang terdekat pada Kitabullah dan sunnah Rasul, baik yang terdekat itu diperoleh dari nash yang terkenal dengan qiyas ( ma'qul nash), atau yang terdekat itu diperoleh dari maksud dan tujuan umum dari hikmah syari'ah yang terkenal dengan "maslaha". (Ibrahim Hoesen,Kontektualisasi Doktrin Islam Dalam Sejarah, h.320 ).

Menurut para ahli dikutip oleh M.Akmansyah, yang dimaksud dengan pemikiran Islam adalah penggunaan akal budi manusia dalam rangka memberikan makna dan aktualisasi terhadap berbagai ajaran Islam. Sehingga dapat disesuaikan dengan tuntutan masyarakat dan perkembangan zaman yang muncul dalam kehidupan umat manusia dalam berbagai bentuk persoalan untuk dicarikan solusinya yang sesuai dengan ajaran Islam. Upaya ini sangat penting dalam rangka menerjemahkan ajaran Islam sekaligus memberikan respons bagi pengembangan ajaran Islam yang sesuai dengan zaman, dari masa ke masa sejak dulu hingga sekarang ini.

Pemikiran Islam perlu terus dicermati, diteruskan dan dikembangkan sesuai dengan kebutuhan dan persoalan yang dihadapi. Ia merupakan sumbangan berharga dan penting untuk terus dikembangkan dalam dunia pendidikan Islam. Di sini terletak pentingnya pemikiran Islam yang merupakan bagian integral, yang dapat menjadi dasar sekaligus sumber dalam kerangka pendidikan Islam.

Pemikiran Islam bersandar kepada hasil ijtihad, sebagai sumber ketiga hukum 
Islam setelah al-qur'an dan al-hadits. Ijtihad berarti usaha keras dan bersungguh ( gigih ) yang dilakukan oleh para ulama, untuk menetapkan, hukum suatu perkara atau suatu ketetapan atas persoalan tertentu.

Eksistensi ijtihad sebagai salah satu sumber ajaran Islam setelah al-qur'an dan alhadits merupakan dasar hukum yang sangat dibutuhkan, terutama pasca Nabi Muhammad Saw.,setiap waktu guna mengantarkan manusia dalam menjawab berbagai tantangan zaman yang semakin menggelobal setiap waktu. Oleh karena perkembangan zaman yang begitu dinamis dan senantiasa berubah, maka eksistensi ijtihad harus senantiasa bersifat dinamis dan senantiasa diperbaharui serta ditindaklanjuti oleh para mujtahid muslim sesuai dengan perkembangan dan kebutuhan manusia, merupakan hal yang mutlak harus dilakukan.

Oleh karena itu, seiring dengan perkembangan zaman yang semakin menggelobal dan mendesak, menjadikan eksistensi ijtihad, terutama di bidang pendidikan, mutlak diperlukan. Sasaran ijtihad pendidikan tidak saja hanya sebatas bidang materi atau isi, kurikulum, metode, evaluasi, atau bahkan sarana dan prasarana, akan tetapi mencakup seluruh sistem pendidikan dalam arti yang luas.

Dalam dunia penidikan, sumbangan ijtihad dalam ikut secara aktif menata sistem pendidikan yang dialogis, cukup besar peranan dan pengaruhnya. Umpamanya dalam menetapkan tujuan pendidikan yang ingin dicapai. Meskipun secara umum rumusan tujuan tersebut telah disebutkan dalam al-qur'an, akan tetapi secara khusus, tujuan-tujuan tersebut memiliki dimensi yang harus dikembangkan sesuai dengan tuntutan kebutuhan manusia pada suatu priodisasi tertentu, yang berbeda dengan masa-masa sebelumnya.

Untuk mencapai tujuan tersebut, diperlukan perumusan sistem pendidikan yang kondusif dan dialektis, dengan tujuan yang ingin dicapai. Sistem pendidikan yang dimaksud meliputi, rumusan kurikulum yang digunakan, metode pendekatan operasionalisasi dalam interaksi proses belajar mengajar, sarana dan prasarana yang digunakan untuk menunjang pencapaian tujuan pendidikan, alat evaluasi yang digunakan, materi yang dikembangkan, serta kebijaksanaan-kebijaksanaan yang secara politis sangat mempengaruhi pencapaian tujuan yang telah dirumuskan.(Jurnal Pengembangan Masyarakat Islam, vol. 8 No. 2, Agustus 2015 ).

Menurut pendapat lain, ijtihad merupakan totalitas penggunaan pikiran dengan ilmu yang dimiliki untuk menetapkan hukum tertentu apabila tidak ditemukan dalam AlQur'an, As-Sunnah, ataupun suatu kasus atau peristiwa tidak ditemukan pada masa Rasulullah SAW.,para sahabat, ataupun pada masa tabiin. Orang yang melakukan ijtihad harus mempunyai otoritas dan kualifikasi sebagai orang yang mampu secara komprehensif dalam bidang keislaman dan bidang lain yang menjadi pendukungnya.

Bagi yang beragama Islam, dasar religiusnya adalah ajaran Islam. Dalam ajaran Islam, pendidikan karakter merupakan perintah Allah SWT, sebagaimana dijelaskan dalam firman-Nya, yang atinya :

a. "Dan hendaklah di antara kamu ada segolongan orang yang menyeru kepada kebajikan, menyuruh berbuat yang ma'ruf, dan mencegah dari yang mungkar. Dan mereka itulah orangorang yang beruntung." ( Q.S. Ali Imran/ $3: 104$ ).

b. "Serulah ( manusia) kepada jalan Tuhanmu dengan hikmah dan pengajaran yang baik, dan berdebatlah dengan mereka dengan cara yang baik. Sesungguhnya Tuhanmu, Dialah yang lebih mengetahui siapa yang sesat dari jalan-Nya dan Dia-lah yang lebih mengetahui siapa yang mendapat petunjuk.” ( Q.S. An-Nahl/ $16: 125$ ). 
c. Kami tidak menurunkan Kitab (Al-Qur'an ); ini kepadamu

Muhammad ), melainkan agar engkau dapat menjelaskan kepada mereka apa yang mereka perselisihkan itu, serta menjadi petunjuk dan rahmat bagi orang-orang yang beriman." (Q.S. An-Nahl/16: 64 ). (Anas Salahudin, 2013, h. 85-86 ).

\section{KESIMPULAN}

Pendidikan karakter yang dikembangkan oleh para pakar pendidikan, landasan utamanya adalah Al-Qur'an dan As-Sunnah. Di dalam Al-Qur'an terdapat beberapa hal yang sangat positif guna pengembangan pendidikan, terutama pendidikan karakter. Al-Qur'an, di samping sebagai sumber hukum Islam, ia juga sebagai sumber inspirasi bagi dunia pendidikan karakter. Sedangkan Al-Hadits juga sebagai sumber pendidikan karakter setelah Al-Qur'an, sumber inspirasi ilmu pengetahuan dan pendidikan. Hal itu dapat dilihat dari bagaimana cara Nabi memainkan perannya sebagai pendidik dan sekaligus sebagai evaluator yang adil, dan tetap menjunjung tinggi nilai-nilai ajaran Islam. Sementara pemikiran Islam berstandar kepada hasil ijtihad, sebagai sumber ketiga hukum Islam. Oleh karenanya, seiring dengan perkembangan zaman yang semakin mengglobal dan mendesak, menjadikan eksistensi ijtihad terutama di bidang pendidikan mutlak diperlukan.

\section{DAFTAR PUSTAKA}

Akmansyah, Jurnal Pengembangan Masyarakat Islam, vol.8, No. 2, Agustus- 2015.

Ali As-Shabuni, Shafwa At- Tafasir, Jilid 11l,h. 581.

Al-Ghazali, Ihya Ulumuddin, Jilid IV, h. 364

Anas Salahudin, Pendidikan Karakter, Pustaka Setia Bandung, 2015
E.Mulyasa, Manajemen Pendidikan Karakter, Bumi Aksara, Jakarta, 2016 Marzuki, Pendidikan Karakter Islam, Bumi Aksara, Jakarta, 2015

Ibrahim Hoesen, Kontekstualisasi Doktrin Islam Dalam Sejarah, Mizan Bandung, 2000.

Terjemah Al-Qur'an, Kementrian Agama, Jakarta, 2015. 